\title{
Bronze Age Warfare in Barbaric Europe - Current Trends and Perspectives in the Future
}

\author{
Davide Delfino* \\ Center for Geosciences of the University of Coimbra, Instituto Terra e Memória, Portugal
}

Submission: February 02, 2018; Published: May 11, 2018

*Corresponding author: Davide Delfino, Center for Geosciences of the University of Coimbra, Instituto Terra e Memória, Portugal, Email: davdelfino@gmail.com

\begin{abstract}
Research on prehistoric warfare is in progress since 60 years. But investigation specifically on Bronze Age period, when some tools are exclusively created for fight and the warrior societies are emerging, is always young. Scholars there were mainly interested on the origins of violence in mankind, on the fighting in the Neolithic or, if Bronze Age, on the wars in the empires of the Near East or in the Minoan civilization. But the warfare in the European Bronze Age up to a decade ago, it was dealt marginally. Violence and warfare in Bronze Age in "barbarian Europe", to use an expression by Jaques Briard, can be defined as a "fashion" since the mid-2000s. Recent trends are analyzed according to various perspectives: generals, theoretical, study of material cultures and context, and interpretative tendencies. So will be discuss what the commonly accepted theories and what also remain subject of doubt and debate to draw a perspective for the future.
\end{abstract}

Keywords: European Bronze Age; Warfare; Literature review; New perspectives; Fashion; Barbaric Europe; Protohistoric; Perspective; Aegean civilizations; Archeology; Anthropology; Paleopathology; Primatological; Paleodemographic; Ethnography; Psychology

\section{Introduction}

Object of the present work will be the review of the work, the state of the art and future research horizons on the warfare in the Bronze Age in the parts of Europe not affected by State-owned societies such as the Aegean civilizations: these include all the European regions that between the end of the third millennium and the first quarter of the first millennium BC know a chiefdom societies and that Jaques Briard has defined "barbaric Europe" (1976).

Violence and warfare in the pre and protohistoric societies are topics dealt with over several decades and under various perspectives. A first approach on prehistoric war had been by Childe [1] in which we doubt the peaceful nature of primitive populations and the war as a factor linked to the most advanced societies. But the beginning of what will be the great debate on the nature of the prehistoric war, or ritual or real, coincides with the first two real works focused on the violence in prehistoric society, by is theory by Clastres [2] who denied the real violence in the prehistoric societies, as Leroi Gourán [3], where hunting violence was linked to violence of the war, and the reply to tinted out by Lehoerff [4]. Also in 60's appears the first paper on war in European prehistoric societies [5].

In the general topic on war in the prehistory, we will quote only main works after Keeley [6] which created a break with the '70s and' 80 s, combining archeology and anthropology beyond the Neolithic to the Bronze Age and combine archaeological data with paleopathology in the theme of the prehistoric warfare: so, Gulaine \& Zammit [7] which extend the investigation, iconography in rock art and cultural anthropology; Haas [8] analyze the connection between warfare and social evolution; Parker Pearson \& Thorpe [9], who coordinated multidisciplinary work on violence and the warfare between early prehistory and protostory under archaeological, primatological, paleodemographic and paleopathological aspects; Otto, Thrane \& Vandkilde [10] which in a general and multidisciplinary analysis of the relationship between the warfare and the human society, gives a certain space to the pre and protohistoric period; Ralph [11] which together with other authors makes a panorama of the archaeological traces of violence from prehistory to medieval age; Fry (2013), who together with other authors takes into account the violent or peaceful nature of mankind in an evolutionary context; Hallen \& Jones [12] who examine with other authors the origin of violence in mankind by analyzing the communities of today's hunter-gatherers, and Vander worker \& Wilson [13] who in a work with other authors deal with the theme of the relationship between the archeology of warfare and of food in daily, cultural, ritual and technical aspects but only in anthropological data on today traditional societies.

Specifically on the warfare in Bronze Age Europe, a vision will be made on studies concerning in particular the weapons, the defensive architectures, the warrior figure and the social aspects and all that it composes the "warfare", on data and related theories. 


\section{Global Journal of Archaeology \& Anthropology}

\section{Warfare in European Bronze Age a State of Question}

Until 2000's, papers, books and other works have mainly dealt about experimental archaeology on Bronze Age weapons [14-16]; inventory, distribution and chronology of Bronze Ages weapons [17-25]. There is an immediate interest for the Bronze Age weapons in the UK for several volumes of the monumental series "Prahistorische Bronzefunde" [26], for the volumes belonging tothe "Typologie des objects de l' Âge du Bronze en France" [27], as well as for other single works [28] on circulation and development of the weapons [29-32] on regional context $[33,34]$ : work by Osgood didn't have much information on the use of weapons and has been criticized for a too enthusiastic interpretation in start of the British hill forts and some inconsistencies in interpretation of the Early Bronze Age social aspect of warfare [35] ( l'ultimo period non si capisce). Other works have been or in specific chapters on Bronze Age within works about more general chronologies or trans-chronological topics (anche qui non si capisce il period) [36-39], or within archaeometric studies dedicated to weapon technique [40-47], or in function analysis $[48,49]$ or in a interpretative use of weapons [50-52], or in symbolism of the weapons or of the warrior [53], or, though the context of a more general chronological context, in social and cultural dimension of violent acts [54]. In the late 90's the warfare in prehistory was defined a "young and brave field" [55]. An important initial work on that "young and brave field" is the one by Osgood, Monks and Toms [56] where for the first time the problem of warfare in "barbaric Europe" Bronze Age has been dealt with in a work entirely dedicated to it. , above all in the theoretic issues: what was the warfare in the Bronze Age like? How was the fighting mode and for what purposes were the fortified structures built?

After 2000's works on warfare in Bronze Age they seem more systematic. An initial work by Vandkilde [57] draws attention to a more rational study of war, especially during the Bronze Age, which breaks away from the two paradigms which have perhaps misinterpreted this aspect during the XX century: the excessive pacifism of prehistoric people and the "celebration" of the war along the millennia. On the one hand, not exclusively dedicated to the warfare, the work by Kristiansen \& Larsson [58] illustrates the iconography, the heroic idealization of warriors and transmission of power symbols related to weapons and their use as a sign of emerging dominant classes and cultural identity, in the context on ideology and social role of warrior in the Bronze Age and its implication in the hierarchization of the society.

In one of the first works that can be defined as "global" on the prehistoric warfare, since they include more disciplines and cover all prehistory in most parts of the world, warfare during the Bronze Age are examined from the point of view of the beginning of warfare in specific cases of Slovakia [59] and of western Iberia [60] in a regional context and its link with the economy and social prestige, demonstrating that warfare in Bronze Age in two different parts of Europe is never isolated from social dynamics, again from the point of view of the study of raiding warrior graves [61], or from the point of view of the interpretation of the increase in weaponry that can be related not with the increase of the conflict but with ideological need of status symbol by elites [62].

In reverse, in a previous work, Kristiansenn [63] demonstrates, after technical analysis on swords, that the weapons are effectively produced and used to fight. The first work ever dedicated exclusively to Bronze Age warfare in Europe, excluding the Aegean area, by Harding [64] describes the development of weapons, defensive systems and the impact of war on the non-warlike population in the Bronze Age in Europe, focusing all the contexts that can give data on the war: he consider warfare to be very local and delimited, carried out by small warriors groups (few dozen) and defines the warfare as "the organized conflict between two peoples or groups with the purposeful intention of inflicting harm", which seems to be the most accepted definition for the warfare in the Bronze Age [65].

On the other hand they appear to reproduce the old utilitarian approach more refined and multidisciplinary, like the work coordinated by Uckelmann \& Moedlinger [66], which can be considered the main and more recent work on use and on the technological development of the weapons along the Bronze Age, covering several parts of Europe. Bronze Age warfare is also entered into national works about the military history [67], witch, that while dedicating a brief chapter on the military history of Spain, brings out the warfare in III- II millennium BC. from anonymity also in historical discipline. A work edited by Jaeger, Czbreszuk \& Fischl [68] traces an overview of the fortified settlements along the Bronze Age and its connection to regional and interregional trade networks, but taking in account only the central Europe and Baltic regions interested by the amber network. In a work exclusively dedicated to a regional analysis of the prehistoric warfare [69], Bronze Age covers an important part, divided in two shares (Bell Beaker/ Early Bronze Age and Later Bronze Age) and interpretations are discussed about the cause of the destruction with the fire of some Bell Beaker/ Early Bronze Ages palisades (by attackers or for ritual), the early presence of swords and shields in Ireland and Great Britain and the percolation of territory and consequent violent competition between human groups in Late Bronze Age. In a short work analyzing the weapons of Baltic area, above all of Bronze Age, Horn [70] stresses that the technical study of weapons as a main point to distinguish the warfare from other forms of violence, and emphasizes the importance of the psychological habitués of the fighters and of the adaptation to this of the shape of the weapons.

The work by Thorp [71] in the most recent companion on European Bronze Age [72], the four main categories used by research on the Bronze Age warfare are defined (weapons, art, fortifications and skeletal analysis of injuries), with some important indications, like: daggers cannot properly be 
considered weapons, difficult to find in the material culture all the exact parallels of the weapons represented in the art, need to identify well the fires and deaths really caused by an attack in the fortified sites and, in the skeletal analysis, Thorp identifies different pieces of evidence of death or injuries in combat both at fortified sites and in burials or on battlefields; furthermore Thorp highlights the problem of the discrepancy of findings (weapons, fortifications, art and skeletons) in the various regions of Europe which may prevent a reliable identification of the warfare.

Other regional study by Molloy shows a case study on Ireland, which, according to the author, can also be extended to the rest of Europe: favoring direct study on weapons (daggers, halberds and axes to Early Bronze Age; swords, spears and shield to Middle Bronze Age and Late Bronze Age) Molloy highlights both-melee combat both distance combat along all the Bronze Age, with particular importance of the invention of the swords and shields since Middle Bronze Age, assuming a close link between the personal characteristics of the warrior and the manufacturing technology of the weapons. Again Bronze Age in Ireland is the focus of another work [73] where the authors analyze the fortified settlements and the warfare in a time span covering the Middle and Late Bronze Age: here the authors sees in Ireland but also in the main part of western Europe the true warfare and the rise of the chiefdom polities active in the consolidation of large regional territories.

In a recent $\mathrm{PhD}$ thesis Lineen [65] in the context of an analysis of the territorial distribution of weapons in Bronze Age Ireland, carries outan interesting overview, resulting from an accurate bibliographic survey, about, among other things, the chronology of appearance and development of all weapons types in Europe during the Bronze Age, and the limits, in great detail, of the analysis of traumas in the bones of the skeletons, which remains essential anyway in the study of warfare.

Coming back to the monumental PBF, a very recent balance of 50 years of the project shows among others a recent view about some issue on the Bronze Age weapons; inside that work, a contribution by Peter Rocher [74] summarizes some more recently shared aspects of the Bronze Age warfare: two types of fight action, namely the feud and the real war with its consequent tactical and social manifestations, the revolutionary role of the invention of the sword in the Middle Bronze Age as the first real object conceived and realized only for the war (sword), the dichotomy between shape and function of the swords with a strong symbolic load for many of them, the introduction of protective weapons like armor only from Late Bronze Age to Central Europe (Urnefield), the origin of combat information is hypothesized to counter the people on horseback in Central Europe may be in Late Bronze Age; Peter- Rocher shows also that for the end of the Bronze Age (Hallstatt B3), the combat tactics for Heunischenburg are documented where it seems that before throwing weapons (arrows) were used and then the melee began, the real war is believed to have begun with combat training and its social implications and the study of the wounds in the bone remains and the wear and tear of weapons is essential in order not to misunderstand true combat or rituality.

The last fundamental work [75] brings together the contributions discussed at an international conference carried out at Gothemburg and analyze the connection between warfare and all the Bronze Age manifestation of social interaction or the various uses of weapons (practical and ritual) and all the aspects of identity of warrior. According to the authors, Bronze Age look a warfare as institutionalized and professionalized, with a construction of a hero- warrior and heroic- warfare.

\section{Some remarks on today vision of the Bronze Age warfare in the "barbaric" Europe}

In the light of the information currently available on material attestations (material culture, contexts, and human remains), by virtue of some acceptable data that emerged from other human sciences (anthropology, ethnography, psychology), and following the development, refutation and global acceptance of the formulated theories, the certain and commonly acceptable vision of the Bronze Age warfare in barbaric Europe are in some aspects well defined. It is now clear that the fight is generated by needs related to the social structure the need to defend or take control over interchange networks, the need, by elites, to manifest their power giving also the certainty of their ability to defend them to their communities, the need of a social group - in many cases coinciding with a professional group- to exercise its activity. In this series of "needs" that link the fight to a social "being", two aspects can be glimpsed: to one hand it can be plausible, in our opinion, to include in the word "warfare" the combat done for economic reasons in a coordinated way by groups composed by more of dozen of warriors (true war), the combat made for other reasons (feud) by a few warriors in an unorganized way, and the combat made not for apparent practical reasons (often called ritual); this last aspect can also include individual struggles for pure training purpose. And why include these three aspects in the word?

For the simple fact that this term can mean the technique of fighting, with all the premises that the early Greek word $\tau \varepsilon$ z $\chi \eta$ imply (know-how, and so experiment, practice, training, passing on of notions). On the other hand Bronze Age it is an era of radical emergence of the elites and of revolutionary technological discoveries (we refer to the bronze technologies): this makes the Bronze Age an exceptional age for the development and consolidation of the warfare, in the light of the close link between these and the social dimension and the technological aspects. According to Thorp \& Lineen $[65,71]$ pieces of evidence of warfare in European Bronze Age are four: weapons/armour, fortifications, skeletal trauma and iconography, though Harding \& Haas [64] includes, respectively, also the social organization for one hand and, to prehistoric societies in general, the burial contexts and the site markers for other hand. 
Specifically on the war technique, and not its symbolism or social role, starting from these pieces of evidence it has been possible to progress a lot in the last 15 years to understand that, among other things: swords are the first objects irrefutably produced for the one purpose of use in fighting, according to studies by Kristiansen \& Molloy [63]; several walled settlements in different parts of Europe are really attacked [71] and that demonstrate that talking about "defended sites" is pertinent also to the Bronze Age in "barbaric" Europe; also it has been demonstrated that the technique of weapons production, above all the swords, knows refined and timely solutions during Middle and Late Bronze Age; finally a recent and amazing find of the Late Bronze Age "battlefield" of Tollense Valley [76] which gave us a fairly precise view of a clash of the Late Bronze Age: according to estimates, some thousand of warriors, who already fought perhaps other battles, fight with arrow points in flint and in bronze, bronze spears in melee, daggers, swords and wooden clubs, fighting so in distance and close combat perhaps with the first documented archers on horseback.

\section{Perspectives}

Relatively several problems and doubts need to be clarified. As far as weapons are concerned, they need work focused on the real use of the swords: if on one hand some scholars think that swords have been hardly used in the slashing role, but more likely to thrusting, on the other hand the shapes of several swords make think to a effective weapons both in slashing, both in thrusting; and others, as Molloy are inclined more for the thrusting attack, not excluding that slashing, depending on the type of sword and on the correct choice of use in combat. So, several study remain to be done in use of weapons, above all in creating continental overview: many works have been done, especially in the last 15 years, but that only concern weapons of specifically region or macro region (Scandinavia, Ireland, Great Britain). As remark Thorp [71] the four pieces of evidence on warfare to the Bronze Age (weapons/armors, fortifications, skeletal trauma and iconography) are spread and known unevenly across the regions: it is necessary to understand if it is based on real data or due to particular circumstances, for example to the weapons caused by the activity of the rubbers. Again, according to Molloy [77] is mandatory to have a line of study in the combined use of weapons in combat.

The study of wounds in the bone remains and the wear and tear of arms are surrounded by a lot of misunderstandings. : many mortal wounds, perhaps due to real combat and not ritual, may not be visible in the bones because they affect soft tissues that have not been preserved, according also to Walker [78] and Lineen [65]. The fact that defense weapons, such as armor and helmets, only appear from the Late Bronze Age, does not mean that for the previous periods they were absent: they could very well have been made with perishable materials, such as hardened leather, and have not been preserved: moreover, they are less protective, but much lighter and more comfortable in combat and perhaps not completely absent even in the Late Bronze Age for most warriors: this therefore does not completely rule out melee combat even before Late Bronze Age (also taking into account the wound factor in soft tissues as cited above).

The evident link between social structure and combat level (more or less close to a true war) should serve to better reconsider some rigid hypotheses that see the real war begin only at the end of Bronze Age: if it is true that this starts with a type of structured society probably closer to the complex chiefdom, it is necessary to consider that evidence such as the fortified citadels of the Iberian south-west, or the megalithic funerary phenomenon, or some complex set graves, already imply some simple chiefdom structures from the Middle and Recent Neolithic in many parts of Europe; it is unlikely that the social structure has not been further complexes until Late Bronze Age, and therefore it would be opportune not to exclude a priori the manifestation of true wars at least during the Middle Bronze Age when swords appear. Also considering that the presence of special weapons could be not the prerequisite, but the consequence of the warfare [79]. By linking to this theme, it is clear that the warfare it is something not only symbolic in the Bronze Age: it is evident that it has a symbolic component, but like all symbolic things it is a practice, before becoming such. And if anyone still has some doubts about it, the example of the Tollense valley it's more than clear.

Finally, in the desirable interdisciplinary work involving both natural sciences, like biology and medicine on the study of injuries and chemistry in the study of weapons, and involving other human sciences as anthropology, ethnography and sociology, it is important to expand the collaboration to others human sciences as psychology [80] and polemology [81], in the perspective that the human mind in a situation of violence and combat has behaviors that, although varying from person to person and from epoch to epoch, still maintains some ancestral characteristics and always induces certain behaviors of circumstance. That can be an immaterial, but scientific and useful, help to research in the material evidences $[82,83]$.

\section{References}

1. Childe VG (1941) War in prehistoric societies. The Sociological Review 33(3,4): 126-138.

2. Clastres P (2013) Archeologie de la violence. La guerre dans les sociétés primitives, (edn), de l’Aube, Paris, France, p.80.

3. Leroi Gouran A (1964) Le geste et la parole. Alban Michel, Paris, France, 2: 323,285.

4. Lehoerff A (2016) Prehistoires d' Europe. De Neardertalà Vercingetorix, (edn), Belin, Paris, France, pp. 604.

5. Escalon de Fronton M (1964) Naissance de la guerre en Occident aux temps préhistoriques. Archeologia, 1: 31-34.

6. Keeley LH (1996) War before civilization. Oxford University Press, Oxford, UK, pp. 245 .

7. Gulaine J, Zammit J (2001) Le sentier de la guerre. Visage de la violence préhistorique, (edn), du Seuil, Paris, pp. 372. 


\section{Global Journal of Archaeology \& Anthropology}

8. Haas J (2001) Warfare and the evolution of culture. In "Archaeology at the Millennium: A Source Book". Feinman G, Price D (Eds.), Springer, New York, USA, pp. 329-350.

9. Parker Pearson M, Thorpe AJN (2005) Warfare, violence and slavery in Prehistory, British Archaeological Reports (Int. Series 1374), Archaeopress, Oxford, UK, pp. 233.

10. Otto T, Thrane H, Vandklide H (2006) Warfare and society: archaeological and social-anthropological perspectives. Aarhus University Press, Aarhus, Europe, pp. 529.

11. Ralph H (2012) The archaeology of violence. Interdisciplinary approach, IEMA Proceeding, State University of New York Press, New York, USA, 2: 306

12. Hallen MW, Jones TL (2015) Violence and Warfare Among HunterGatherers. Left Coast Press, Walnut Creek, CA, USA, pp. 391.

13. Vander warker AMl, Wilson GD (2016) The archaeology of food and warfare. Food insecurity in prehistory, Springer Internation Publishing, Heidelberg, New York, Dordrecht, London, UK, pp. 313.

14. Coles JM (1977) Parade and display experiments in Bronze Age Europe. In: Ancient Europe and the Mediterranean. Studies presented in honour of Hugo Hencken, Warminster, Markotic V (Eds.), Aris and Philips Ltd, USA, p. 51-58.

15. Coles JM (1979) Experimental Archaeology. Accademic Press, London, UK, pp. 274

16. Hermann R, Dolfini A, Crellin RJ, Uckelmann M (2017) Researching Bronze Age swordsmanship: experiments and wear analysis. In The Sword: Form and Thought Martlesham, Suffolk: Boydell \& Brewer. Deutscher L, Kaiser M, Wetzler S (Eds.), In press.

17. Coffey G (1894) Notes on the classification of spearheads of the Bronze Age found in Ireland. Proceeding of Royal Society of Antiquarians of Ireland, 111: 486-510.

18. Brewis WP (1923) The bronze swords in Great Britain. Archaeologia, 73: 253-265.

19. Sprockhoff E (1934) Die germanischen Vollgriffschwerter der jungeren Bronzezeit, Romische-Germanischen Forschungen, 9: 142.

20. O' Riordain SP (1937) The halberd in Bronze Age Europe. Archaeologia, 86: 193-321.

21. Cowen JD (1951) The earliest swords in Britain and their origins on the continent of Europe. Proceeding of Prehistoric Society, 17:195-213.

22. Muller Karpe H (1961) Die Vollgriffschwerter der Urnenfelderzeit aus Bayern, Munchener Beitrag zur Vor-und Fruhgeschichte, 6: 134.

23. Coles JM (1962) European Bronze Age Shields. Proceeding of the Prehistoric Society, 28: 156-190.

24. Eogan G (1965) Catalogue of Irish Bronze Swords. National Museum, Dublin, Europe, pp. 230.

25. Patay P (1968) Unrnenfelderzeitlitche Bronzeschilde in Karpatenbecken, Germania, Europe, 46: 241-248.

26. Dietz U, Jockenhovel A (2016) 50 Jahre Prähistorische Bronzefunde Bilanz und Perspektiven, PBF, abt. XX, Band 14, Steiner Verlag Munchen, Germany, pp. 420.

27. Gaucher G, Mohen JP (1972) Typologie des objects de l'Âge du Bronze en France. $7^{\text {th }}$ volume, Societès Préhistorique Francaise, France.

28. Hencken H (1971) The earliest European helmets. Bronze Age and early Iron Age. American School of Prehistoric Research, Peaboby Museum Press, Cambridge, UK, pp. 200.

29. Cowen JM (1955) Eine Einfuhrun in die Geschichte der bronzenen Griffzungenscwerter in Suddeitchland und den angrenzenden Gebieten. Deutsches Archalogisches Institut, Germany.
30. Trump B (1962) The origin and development of Middle Bronze Age rapiers. Proceeding of the Prehistoric Society, 28: 80-102.

31. Brown MA (1982) Swords and sequences in the British Bronze Age. Archaeologia, 107: 1-42.

32. Kristiansen, K. (1984) Krieger und Hauptlinge in der bronzezeit Denmark. Ein beitrag zur Geschichte der bronzezeitlitchen Schwertes, Jahrbuch des Romische-Germanischen Zentralmuseum 31: 187-208.

33. Osgood R (1998) Warfare in the Late Bronze Age of North Europe. British Archaeological Report, International Series 694, Archaeopress, Oxford, UK, p. 128.

34. Barcelo JA (1999) Patriarcs, bandits and warriors. An analysis of social interaction in Bronze Age south western Iberian Peninsula. In: Elten in der bronzezeit, Monographien der Romischen-Germanischen Zentralmuseum, Verlag der Romische-Germanischen Zentralmueseum, Mainz, Clausing C, Egg M (Eds.), 43: 223-243.

35. Needham S (1999) Osgood Richard: Warfare in the Late Bronze Age of North Europe B.A.R. International series 694 xiii 192 pages, 1 colour plate \& numerous black \& white illustrations. 1998. Oxford: Archaeopress; UK, 0-86054-878-3 paperback, Antiquity 73 (279): 232-232.

36. Oakeshott E (1960) The archaeology of weapons, Boydell and Brewer, London, p. 416.

37. Petres EF (1982) Neue Angaben uber die Verbreitung der spatbronzezeitlichen Schutzwaffen, Savaria 16: 57-80.

38. Harding A (1999) Warfare: a defining characteristic on Bronze Age Europe. In: Ancient warfare, Sutton, Stroud; Charman J, Harding A (Eds.), pp. 157-173.

39. Kristiansen K (1999) The emergence of warrior aristocracies in Later European Prehistory and their long-Tterm History. In: Ancient warfare, Stroud, Sutton; Carman J, Harding A (Eds.), p. 27-43.

40. Drescher H (1961) Die Gusstechnik des Vollgriffschwertes aus Mackelfeld, Kreis Harburg, Hamaburg, 7: 57-66.

41. Driehaus J (1961) Rontgenuntersuchungen an Bronzenen Vollgriffschwerten. Germania 39: 22-31.

42. Hundt HJ (1965) Produktiongeschichtlitche untersuchungen über den bronzezeitlichen schwertguss. Jahrbuch des Romische-Germanischen Zentralmuseum, p. 41-58.

43. Anker D (1977) Rontgenuntersuchungen an Riegseeschwerten. Ein beitrag zur typologie, Archaeologie and Naturwissenschaften 1: 269459.

44. Liebel D (1985) Reconstruction des Bronze-swerves von Steen in original truer technique, Restaurierung und Museumtechnik 6: 39-53.

45. Wustermann H (1992) Jungbronzezeitliche Vollgriffschwerter mit bleifullung, Arbeits und Forschungsberichte zur sachsischen Bodendenkmalpflegge 35: 39-49.

46. O’ Faolain S, Northover JP (1998) The technology nof Late Bronze Age Sword Production in Ireland. Journal of Irish Archaeology 9: 69-88.

47. Longaureova M, Longauer S, Makarius P (1999) Metallography of Ancient Bronze Swords. In: Vychodoslovensky Pravek, Special Issue: Archaeometallurgy in Central Europe, Mihok L, Mirossayova E (Eds.), Archeologicky ustav SAV, Slovakia, Europe, p. 77-95.

48. Savage RDA (1979) Technical notes on the Watford sword fragment In: Bronze Age Hoards: some finds old and new", British Archaeological Reports, British Series 67, Burgess, C and Coombs, D. (eds), Archaeopress, Oxford, England, UK,pp. 221-228.

49. Ramsey G (1993) Damaged butts and torn rivets holes: the hafting and function of Middle Bronze Age "dirks " and "rapiers". Archaeometarials 7: 127-138. 
50. Wall J (1987) The role of daggers in Early Bronze Age Britain: the evidences of wear analysis. Oxford Journal of Archaeology 6(1): 115118.

51. Lenherz de Wilde M (1991) Uberlegungen zur Funktion der fruhbronzezeitlichen Stabdolche. Germania, Europe 69: 25-48.

52. Brigdford SD (1997) Mighter then the pen? (An edgewise look at Irish Bronze Age swords). Material arm: Archaeological Studies of War and Violence, In Carman (edn), Cruitne Press, Glasgow, UK, pp. 95-115.

53. Treherne P (1995) The warrior's beauty: the masculine body and self identity in Bronze Age Europe. Journal of European Archaeology 3(1): 105-144.

54. Carman J (1997) Material Harm: Archaeological Studies of War and Violence. Cruitne Press, Ireland, pp. 258.

55. Redmond EM (1998) Material Harm: Archaeological Studies of War and Violence. Jhon Carman, Review, Fokkens H, Harding A (Eds.), 63(2): 338-339.

56. Osgood R, Monks S, Toms J (2000) Bronze Age warfare, The History Press Ltd, Stroud, UK, pp. 165.

57. Vandkilde H (2003) Commemorative tales: Archaeological responses to modern myth. politics, and war, World Archaeology 35(1): 126-144.

58. Kristiansen K, Larsson TB (2005) The Rise of Bronze Age Society: Travels. Transmissions and Transformations. Cambridge University Press, Edimburg, USA, pp. 449.

59. Harde A (2005) The emergence of warfare in early Bronze Age: the Nitra Group in Slovakia and in Moravia (2200-1800 BC), In: Warfare, violence and slavery in Prehistory, British Archaeological Reports (Int. Series 1374), Parker Pearson M, Thorpe AJN (Eds.), Archaeopress, Oxford, UK, pp. 87-105.

60. Aranda Jimenez G, Sanchez Moreno M (2005) The origins of warfare: later prehistory in southeastern Iberia. In Warfare, violence and salvery in Prehistory, British Archaeological Reports (Int. Series 1374), Parker Pearson M, Thorpe AJN (Eds.), Archaeopress, Oxford, UK, pp. 181-194.

61. Osgood R (2005) The death of Tormaton, Middle Bronze Age combat victime? In: Warfare, violence and slavery in Prehistory, British Archaeological Reports (Int. Series 1374), Parker Pearson M, Thorpe AJN (Eds.), Archaeopress, Oxford, UK, pp. 139-144.

62. Fontijn D (2005) Giving up weapons. In: Parker Pearson M, Thorpe AJN (Eds.), Warfare, violenceand salvery in Prehistory, British Archaeological Reports (Int. Series 1374), Archaeopress, Oxford, UK, pp. 145-154.

63. Kristiansen K (2002) The Tale of the Sword: Swords and Swordfighters in Bronze Age Europe. Oxford Journal of Archaeology 21: 319-332.

64. Harding A (2007) Warriors and weapons in Bronze Age Europe. Archaeolingua Alapitávny, Budapest, Hungary, pp. 224.

65. Lineen J (2017) Spearheads in the Landscape: a Contextual Analysis, $\mathrm{PhD}$ thesis submitted for the degree MPhil, Department of Archaeology, University College Cork, Cork, Europe, pp. 236.

66. Uckelmann M, Moedlinger M (2011) Bronze Age Warfare: Manufacture and Use of Weaponry, B.A.R. International Series 2255, Archaeopress: Oxford, UK, pp. 219.

67. Almagro Gorbea M (2009) Edade del Bronce, In Prehistoria y Antiguedad, Historia Militar de España. Ministero de la Defensa y Ediciones del Laberinto. Almagro Gorbea M (edn), Madrid, Spain,p. 49-60.
68. Jaeger M, Czbreszuk J, Fischl KP (2012) Enclosed space - Open society. Contact and exchange in the context of the Bronze Age fortified settlements in Central Europe, Studien zu Archaeologie in Ostmitteleuropa, 9, Dr. Rudolf Habelt Verlag, Bonn, pp. 371.

69. Heat J (2009) Warfare in prehistoric Britain. Amberley Publishing, Struod, England, UK,pp. 160.

70. Horn C (2013) Harm's way. An Approach to Change and Continuity in Prehistoric Combat. Current Swedish Archaeology 21: 93-116.

71. Thorp N (2013) Warfare in the European Bronze Age. In: The Oxford Handbook of the European Bronze Age, Fokkens H,Harding A (Eds.), Oxford University Press, Oxford, UK, pp. 234- 247.

72. Fokkens H, Harding A (2013) The Oxford Handbook of the European Bronze Age, Oxford University Press, Oxford, UK, pp. 969.

73. O' Brian W, O' Driscoll J (2017) Hillforts, Warfare and Soiciety in Bronze Age Ireland, Archaeopress Publishing Ltd, Oxford, UK, pp. 522.

74. Peter Rocher H (2016) Die bronzezeit - heroisches zeitalter oder wiege des modernen krieges? In 50 Jahre Prähistorische Bronzefunde Bilanz und Perspektiven, PBF, abt. XX, Band 14, Steiner Verlag, Munchen, Dietz U, Jockenhovel, A. (Eds.), pp. 267-275.

75. Horn C, Kristiansen K (2018) Warfare in Bronze Age society. Cambridge University Press, Cambridge, USA, pp. 400.

76. Brinker U, Schramm A, Jantzen, D, Piek J, Hauenstein K, et al. (2016) The Bronze Age battlefield in the Tollense Valley, MecklenburgWestern Pomerania, Northeast Germany - Combat marks on human bones as evidence of early warrior societies in northern Middle Europe? In The emergence of warrior societies and its economic, social and environmental consequences, Late Prehistory and Protohistory: Bronze and Iron Age, Proceeding of the thematic session A3a of XVII U.I.S.P.P. World Congress, Coimbra F, Delfino D (Eds.), Archaeopress Publishing Ltd, Oxford, UK, p. 39-56.

77. Molloy B (2011) Use - wear analysis and use patterns of Bronze Age swords, In: Bronze Age Warfare: Manufacture and Use of Weaponry, B.A.R. International Series 2255, Uckelmann M, Moedlinger M (Eds.), Archaeopress, Oxford, UK, p. 67-84.

78. Walker P (2001) A Bioarchaeological Perspective on the History of Violence. Annual Review of Anthropology 30: 573-596.

79. Molloy B (2012) Martial Minoans? War as Social Process, Practice and Event in Bronze Age Crete. The Annual of the British School at Athens 107: 87-142.

80. Delfino D (2016) Walled enclosures in west Europe as marks of conflicts in Late Prehistory. A psychological, anthropological and archaeological approach, In: The emergence of warrior societies and its economic, social and environmental consequences, Late Prehistory and Protohistory: Bronze and Iron Age, Proceeding of the thematic session A3a of XVII U.I.S.P.P. World Congress, Coimbra F, Delfino D (Eds.), Archaeopress Publishing Ltd, Oxford, UK, p. 3-14.

81. Berruti G, Ruzza S (2016) The emergence of war in human society. In: The emergence of warrior societies and its economic, social and environmental consequences, Late Prehistory and Proto history: Bronze and Iron Age, Proceeding of the thematic session, World Congress, Coimbra F, Delfino D (Eds.), Archaeopress Publishing Ltd, Oxford, UK, p. 27- 38.

82. Briard J (1976) L'âge du bronze en Europe barbare. Des mégalithes aux Celtes, (edn), des Hespérides, Toulouse, pp. 376.

83. Review of Anthropology 30: 573-596. 
CC (1) This work is licensed under Creative BY DOI: 10.19080/GJAA.2018.04.555628
Your next submission with Juniper Publishers

will reach you the below assets

- Quality Editorial service

- Swift Peer Review

- Reprints availability

- E-prints Service

- Manuscript Podcast for convenient understanding

- Global attainment for your research

- Manuscript accessibility in different formats

( Pdf, E-pub, Full Text, Audio)

- Unceasing customer service

Track the below URL for one-step submission https://juniperpublishers.com/online-submission.php 